\title{
Effect of Petroleum on Haematological Parameters and Lead Level in Fuel Attendants in Port Harcourt, Nigeria
}

\author{
Christian, Serekara Gideon*; Elekima, Ibioku; Obisike, Uchechukwu Achor; Aleru, Constancy Prisca \\ Department of Medical Laboratory Science, Rivers State University of Science and Technology, Nkpolu-Oroworukwo, Port Harcourt, \\ Nigeria
}

\begin{abstract}
Petroleum is a thick, flammable, yellow-to-black mixture of gaseous, liquid, and solid hydrocarbons that occur naturally beneath the earth's surface, its products are got from fractional distillation of crude. These products are normally dispensed from reservoir by fuel attendants to motorist and individuals that needs these products for domestic uses. Occupational exposure to petroleum products has been reported to have toxic effects on humans with much impact on the respiratory system. The aim of our study was to investigate the effect of petroleum products on haematological parameters and lead levels. Fifty eight (58) adult human subjects aged between 19 to 52 years were recruited for the study after they gave us consent. Questionnaires were distributed to participants and it was filled with proper guidance. Eight fuel stations located in Port Harcourt, Nigeria, were used as locations for the study and they represent the test subjects, while students from Rivers State University of Science and Technology, Port Harcourt, were recruited as control subjects. A total of eighteen (18) females were enrolled in the study, nine (9) of them for test and control subjects, while a total of 40 males were enrolled, 20 of them for test and control subjects. Graphpad Prism 5.0 statistical package was used to analyse the data obtained. From our findings, there was no statistically significant difference $(p \leq 0.05)$ in most haematological parameters (haemoglobin level, packed cell volume, platelets) and levels of lead in fuel attendants and control subjects. The white blood cells indicated a highly significant difference $(p=0.0001)$ in fuel attendants and may be as a result of chronic exposure to lead and petroleum products.
\end{abstract}

Keywords: Petroleum, Haematological Parameters, Lead, Fuel Attendants

\section{Introduction}

Petroleum is a thick, flammable, yellow-to-black mixture of gaseous, liquid, and solid hydrocarbons that occurs naturally beneath the earth's surface and can be separated into fractions including natural gas, gasoline, naphtha, kerosene, fuel and lubricating oils, paraffin wax, and asphalt and is used as raw material for a wide variety of derivative products [1]. Petroleum products have found its usage in our everyday life and hence the need for fuel attendants to dispense fuel from its reservoir.

In Nigeria, Port Harcourt is one of the major cities where oil exploration takes place and due to lack of steady power supply, the consumption of petroleum products is on the increase. Apart from the use of fuel in automobiles, residence in Port Harcourt demands for fuel more often and this is the reason behind more exposure of fuel attendants to petroleum products as their services are needed to service and dispense petroleum products to end users.

Occupational exposure to petroleum products and fumes has been reported to have toxic effects on various organs and body systems with high impact on the human respiratory system. Organs such as the heart, lungs, skin and kidneys are affected by these toxic effects resulting in various diseases and different forms of genotoxic, mutagenic, immunotoxic, carcinogenic and neurotoxic manifestations [2]. With the fumes from petroleum products and lead content in fuel having a negative impact on the organs of the body, there will be evident impact on haematological parameters which we will investigate.
Previous research studies have been carried out in Calabar, Nigeria on the effect of petroleum product inhalation on some haematological indices of fuel attendants. Their results indicate that the petroleum fume causes a reduction in haematological indices in fuel attendants, which worsens with prolonged exposure [3]. In research carried out on rats, it was observed that the toxicity effect of diesel fuel on haematological parameters causes decreased haemoglobin concentration, packed cell volume, and white blood cell with increasing levels of diesel fuel [4]. In experimental rabbit, upon crude oil ingestion, they observed linear increase in red blood cell count and white blood cell count [5]. Recently, a research study on chronic inhalation of petroleum products on haematological parameters observed decreased haemoglobin percentage, red blood cell counts and total leucocyte counts when compared with control subjects and concluded that chronic exposure to petroleum fumes has adverse effects on human haematopoietic system [6].

Research studies on lead have been carried out on humans and fishes. On fishes, Clarias gariepinus, it was observed that lead significantly cause a decline in haemoglobin levels, packed cell volume and red blood cell counts [7], but base on exposure to lead from petroleum products as observed in automobile workers, there is a significant increase in blood lead $(\mathrm{P}<0.001)$ in the research study by [8].

Hence the present study was carried out to assess if such changes as observed by other researchers is same with fuel attendants in Port Harcourt, Nigeria, by investigating the haematological parameters through full blood counts. We also assessed the lead levels in the different study groups. 


\section{International Journal of Science and Research (IJSR) \\ ISSN (Online): 2319-7064 \\ Index Copernicus Value (2013): 6.14 | Impact Factor (2014): 5.611}

\section{Materials and Methods}

\subsection{Subjects}

This study was carried out on 58 adult human subjects aged between 19 to 52 years who gave informed consent to the study. Questionnaires were distributed and accurately filled by the participants with guidance; participants who met the criteria for participation in this study were admitted into the study. Eight fuel stations located in Port Harcourt, Nigeria, were used as locations for this study and they represent the test subjects, while students from Rivers State University of Science and Technology, Port Harcourt, were recruited as control subjects. A total of 18 females were enrolled in the study, 9 females respectively for test and control subjects, while a total of 40 males were enrolled, 20 males respectively for test and control subjects.

\subsection{Sample}

Venous blood ( $5 \mathrm{ml}$ ) was taken from a peripheral vein on the arm of each subject and immediately transferred into $K_{3}$ potassium EDTA anticoagulant bottles $(3 \mathrm{ml})$ for haematological analysis and the remaining $2 \mathrm{ml}$ into a plain sterile bottle for the estimation of lead. The samples were left to stand at room temperature for about 10 minutes and transferred to a cooler containing crushed ice for transportation to the laboratory, and later kept at room temperature for 30 minutes before analysis. Samples in the plain bottles were spun at 2500rpm for 5 minutes to obtain serum.

\subsection{Methods}

Haematological analysis for full blood count was performed by an automated analyser using Sysmex KS-21-N to obtain all haematological parameters. The blood samples were well mixed with the aid of an automated mixer before analysis. The blood samples obtained were analysed on daily basis.

Lead was estimated by the use of AAS (Atomic Absorption Spectrometry) analyser Raleigh WFX320. Serum was deproteinized by mixing $1 \mathrm{ml}$ of serum with $9 \mathrm{ml}$ of $10 \%$ Trichloroacetic Acid and $0.1 \%$ Lanthanium solution. The mixture was centrifuged for 5 minutes at 2,500rpm. The supernatant was transferred into a universal container and diluted using $0.11 \%$ Lanthanium. A $1: 1$ dilution of the supernatant was made using distilled water and aspirated into an atomic absorption spectrophotometer. The blank and standard were prepared using glycerine $10 \%$.

\section{Results}

The results obtained from the research were tabulated. The mean and standard deviation of the recorded parameters were calculated, and are presented in Table 1 below:

Table 1: Mean \pm Standard Deviation and P-value of Haematological Parameters carried out in the study

\begin{tabular}{|c|c|c|c|c|}
\hline Haematological Parameters & Study Group (Fuel Attendants) & Control Group & P-value & Remark \\
\hline Haemoglobin Concentration (g/dl) & $14.08 \pm 1.50$ & $13.43 \pm 1.58$ & 0.1158 & NS \\
\hline Packed Cell Volume (\%) & $42.60 \pm 3.93$ & $41.03 \pm 4.36$ & 0.1561 & NS \\
\hline RBC (X 109/L) & $5.0 \pm 0.4$ & $5.1 \pm 0.5$ & 0.5209 & NS \\
\hline WBC (X 1012/L) & $5.8 \pm 1.4$ & $4.3 \pm 1.2$ & 0.0001 & S \\
\hline Granulocytes(X109/L) & $2.3 \pm 0.8$ & $1.8 \pm 0.7$ & 0.0074 & $\mathrm{~S}$ \\
\hline Lymphocytes (X109/L) & $2.9 \pm 1.0$ & $2.1 \pm 0.4$ & 0.0005 & $\mathrm{~S}$ \\
\hline Monocytes (X 109/L) & $0.5 \pm 0.27$ & $0.3 \pm 0.20$ & 0.0005 & $\mathrm{~S}$ \\
\hline Platelets $(\mathrm{X} 109 / \mathrm{L})$ & $239 \pm 63$ & $219 \pm 53$ & 0.1900 & $\mathrm{NS}$ \\
\hline Lead $(\mu \mathrm{g} / \mathrm{dl})$ & $20.70 \pm 2.64$ & $19.93 \pm 2.26$ & 0.2401 & $\mathrm{NS}$ \\
\hline
\end{tabular}

KEY: NS = Not significant

\section{$\mathrm{S}=$ Significant}

Comparison of mean values of all parameters were made between the study group and control group, and p-values obtained, which is also presented in the Table 1 above. The mean \pm standard deviation of haemoglobin concentration $(\mathrm{g} / \mathrm{dl})$ in study group was $14.08 \pm 1.50 \mathrm{~g} /$ dland $13.43 \pm 1.58$ $\mathrm{g} / \mathrm{dl}$ in control group as shown in Figure 1 below.

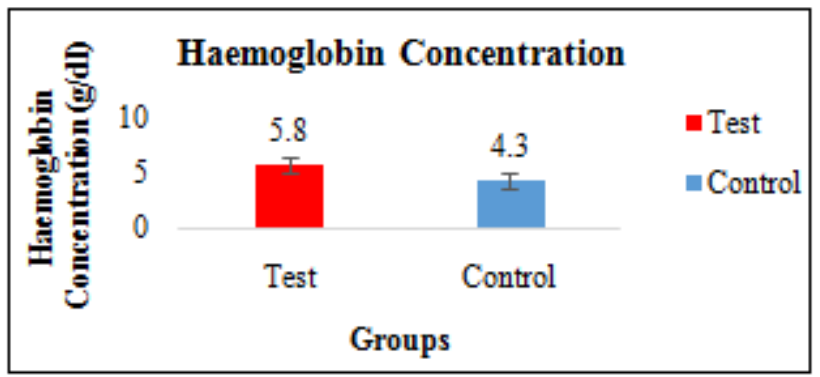

Figure 1: Chart showing mean values of Control and Test subjectsHaemoglobin Concentration
That of packed cell volume (\%) was $42.60 \pm 3.93 \%$ and $41.03 \pm 4.36 \%$ for study and control group respectively, shown in figure 2 .

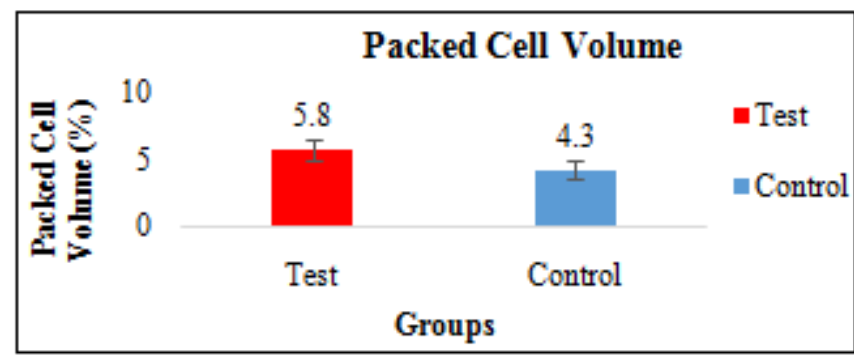

Figure 2: Chart showing mean values of Control and Test subjects for Packed Cell Volume

For RBC counts $\left(\mathrm{X} 10^{12} / \mathrm{L}\right)$ we got $5.0 \pm 0.4 \mathrm{X} 10^{12} / \mathrm{L}$ and 5.1 $\pm 0.5 \mathrm{X} 10^{12} / \mathrm{L}$ for study and control group respectively, shown in figure 3. 
International Journal of Science and Research (IJSR)

ISSN (Online): 2319-7064

Index Copernicus Value (2013): 6.14 | Impact Factor (2014): 5.611

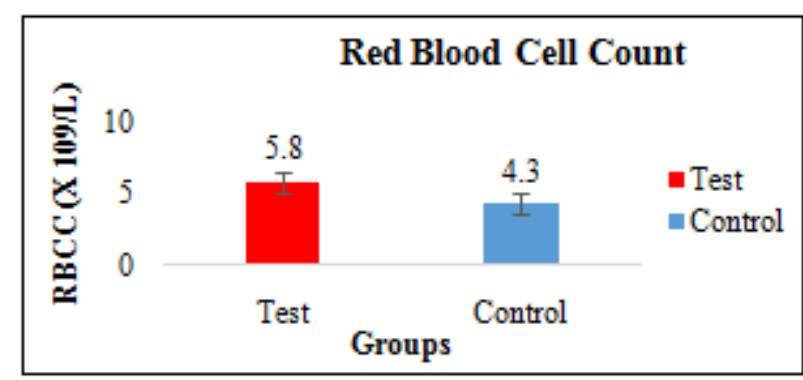

Figure 3: Chart showing mean values of Control and Test subjects for Red Blood Cell Count

Mean WBC counts (X $10^{9} / \mathrm{L}$ ) was found to be $5.8 \pm 1.4 \mathrm{X}$ $10^{9} / \mathrm{L}$ and $4.3 \pm 1.2 \mathrm{X} 10^{9} / \mathrm{L}$ for study and control groups respectively shown in figure 4 .

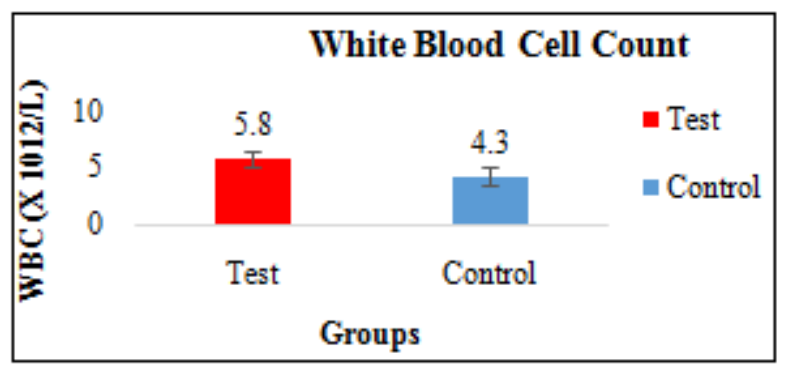

Figure 4: Chart showing mean values of Control and Test subjects for White Blood Cell Count

For differential WBC counts (X $10^{9} / \mathrm{L}$ ) (shown in the chart below, figure 5) we got the following respective results for study and control groups as follows: granulocytes $2.3 \pm$ $0.810^{9} / \mathrm{L}$ and $1.8 \pm 0.710^{9} / \mathrm{L}$; lymphocytes $2.9 \pm 1.010^{9} / \mathrm{L}$ and $2.1 \pm 0.410^{9} / \mathrm{L}$; monocytes $0.5 \pm 0.2710^{9} / \mathrm{L}$ and $0.3 \pm$ $0.2010^{9} / \mathrm{L}$.

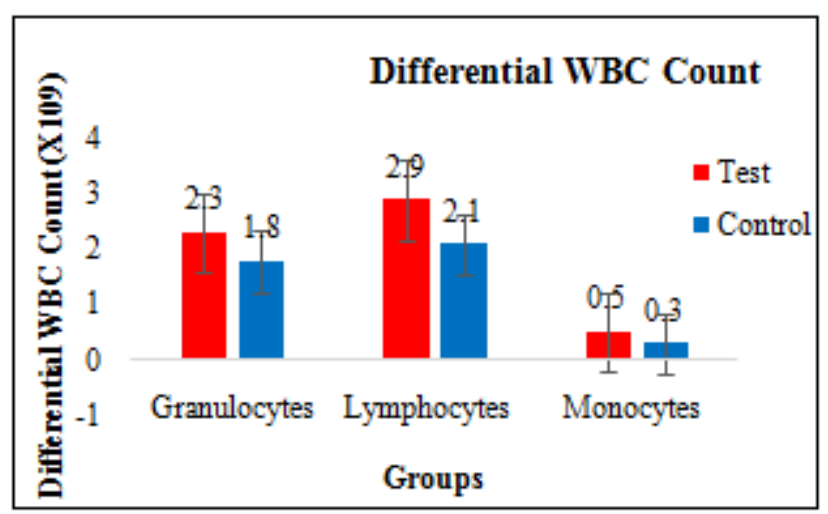

Figure 5: Chart showing mean values of Control and Test subjects for White Blood Cell Count

Also, results for platelet counts were measured to be $239 \pm$ $63 \mathrm{X} 10^{9} / \mathrm{L}$ and $219 \pm 53 \mathrm{X} 10^{9} / \mathrm{L}$ for study and control groups respectively and finally, in our measurement of lead $(\mu \mathrm{g} / \mathrm{dl})$ we got $20.70 \pm 2.64 \mu \mathrm{g} / \mathrm{dl}$ and $19.93 \pm 2.26 \mu \mathrm{g} / \mathrm{dl}$, (figure 7).

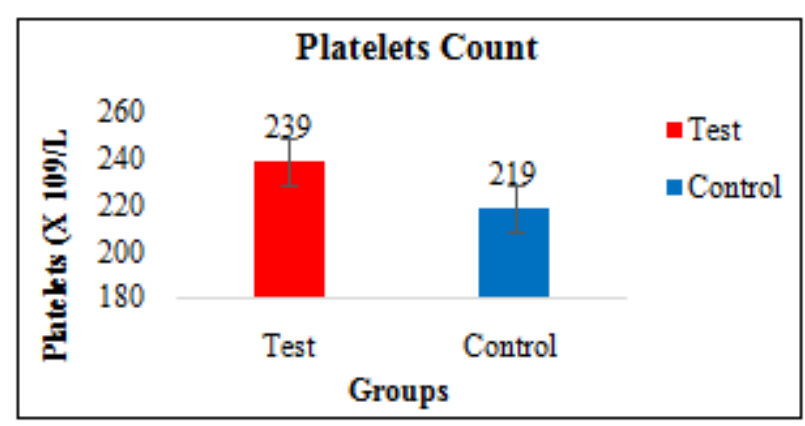

Figure 6: Chart showing mean values of Control and Test subjects for White Blood Cell Count

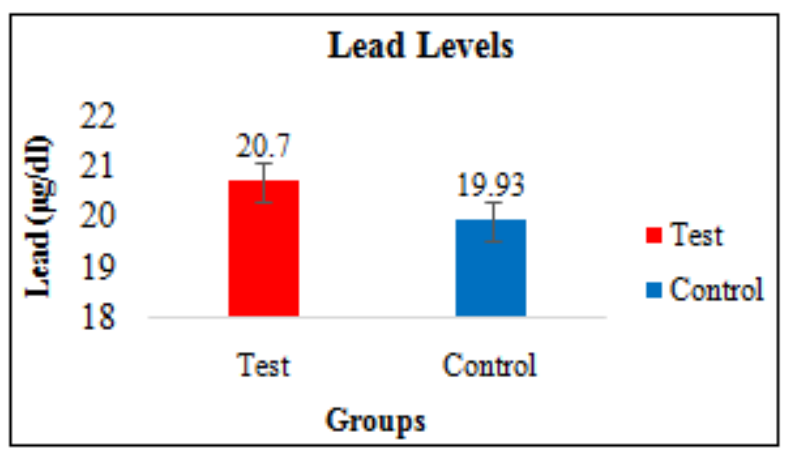

Figure 7: Chart showing mean values of Control and Test subjects for Lead levels

\section{Discussion}

From the results obtained in the study, a statistical significant difference was observed in WBC counts $(\mathrm{p}=$ $0.0001)$, granulocytes $(\mathrm{p}=0.0074)$, lymphocytes $(\mathrm{p}=$ $0.0005)$ and monocytes ( $\mathrm{p}=0.0005)$ between fuel attendants (study group) and control group, while there were no significant statistical difference in haemoglobin concentration, packed cell volume, red blood cell count.

Our findings is different from the study of [3], were they observed a decrease in haemoglobin concentration, packed cell volume and WBC counts in fuel attendants in Calabar, Nigeria. There were no agreement in our findings and that of theirs, taking into cognisance the number of our subjects.

Also, our findings partially agrees with another study by [6], as they observed statistically significant difference in total leucocyte count $(\mathrm{p}<0.05)$ and that of our study was statistically highly significant $(\mathrm{p}=0.0001)$. Other parameters (haemoglobin and red blood cell count) in our study were not in agreement with that of [6] as there was no significant difference in our study when compared to theirs.

In our study on lead, we observed no statistical significant difference in our study population and this is different (a disagreement) from the study by [8], though their work was done on automobile workers, with a highly statistical significant difference ( $p<0.0001$ ). The comparison was made because both populations (fuel attendants and automobile workers) are exposed to the same source of lead which is present in petrol. 


\section{Conclusion}

From our findings, there are no statistically significant difference in haematological parameters (haemoglobin level, packed cell volume, platelets) and level of lead in fuel attendants and control subjects. The white blood cells indicated a highly significant difference in fuel attendants and may be as a result of chronic exposure to lead and petroleum products. The reasons why there were no significant difference between control subjects and fuel attendants might be as a result of the exposure to gasses from petroleum refining company located in Port Harcourt, Nigeria.

\section{References}

[1] American Association of Petroleum Geologist, (2012). What is Petroleum?

[2] Ross, D. (1996). Metabolic Basis of Benzene Toxicity (Review). European Journal of Haematology, 60: 111118.

[3] Okoro, A.M., Ani, E.J., Ibu, J. O., and Akpogomeh, B. A. (2006). Effect of Petroleum Products Inhalation on some Haematological Indices of Fuel Attendants in Calabar Metropolis, Nigeria.Nigerian Journal of Physiological Sciences,21(1-2):71-75.

[4] Dede, E. B. and Kagbo, H. D. (2002). A Study on the Acute Toxicological Effects of Commercial Diesel Fuel in Nigeria In Rats (Ratus ratus) using Haematological Parameters. Journal of Applied Science and Environmental Management, 6(1):84-86.

[5] Ovuru, S. S., and Ekweozor, I. K. E. (2004). Haematological changes associated with crude oil ingestion in experimental rabbits.African Journal of Biotechnology,3(6): 346-348.

[6] Aleemuddin, M., Babu, M. G., Manjunath, M. L. and Quadri, S. S. (2015). Effect of Chronic Inhalation of Petroleum Products on Haematological Parameters. International Journal of Current Research and Academic Review, 3(4): 196-201.

[7] Mahmoud, U. M., Ebied, A. M. and Mohamed, S. M. (2013). Effect of lead on some haematological and biochemical characteristics of Clarias gariepinus dietary supplemented with lycopene and vitamin E. Egyptian Academic Journal of Biological Science, 5(1): 67 - 89.

[8] Dongre, N. N., Suryakar, A. N., Patil, A. J., Ambekar, J. G. and Rathi D. B. (2011). Biochemical Effects of Lead Exposure on Systolic \& Diastolic Blood Pressure, Heme Biosynthesis and Hematological Parameters in Automobile Workers of North Karnataka (India). Indian Journal of Clinical Biochemistry, 26(4):400-406. 